Check for updates

Cite this: RSC Adv., 2017, 7, 24011

Received 21st January 2017

Accepted 27th April 2017

DOI: 10.1039/c7ra00892a

rsc.li/rsc-advances

\section{Synthesis of fused tricyclic indolizines by intramolecular silver-mediated double cyclization of 2-(pyridin-2-yl)acetic acid propargyl esters $\dagger$}

\author{
Hai-Yuan Zhao, $\ddagger^{\mathrm{a}}$ Ying-chun Wang, $\ddagger^{\mathrm{b}}$ Xiao-Lin Cao, ${ }^{\mathrm{a}}$ Qiu-Fang Pang, ${ }^{a}$ \\ Heng-shan Wang (D)*a and Ying-ming Pan (D)*a
}

\begin{abstract}
The treatment of a toluene solution of easily accessible 2-(pyridin-2-yl)acetic acid propargyl esters with 2.0 equiv. of $\mathrm{Ag}_{2} \mathrm{CO}_{3}$ in the presence of potassium acetate (2.0 equiv.) at $100{ }^{\circ} \mathrm{C}$ afforded fused tricyclic indolizines in good to excellent yields. The reaction proceeded through a domino silver-mediated double cyclization sequence involving a 5-exo-dig cyclization and 1,3-hydrogen shift followed by an intramolecular cycloisomerization.
\end{abstract}

The indolizine ring system is prevalent in a wide range of natural and synthetic compounds and possesses different biological and pharmacological activities, ${ }^{1}$ such as anti-inflammatory, ${ }^{1 e}$ antimicrobial, ${ }^{1 g}$ antioxidant, ${ }^{1 h-i}$ and 5 -HT3 receptor antagonist ${ }^{1 j}$ activities, to name a few. It is also used as a building block in the syntheses of many bioactive and heterocyclic compounds. ${ }^{2}$ Among such compounds, fused polycyclic indolizines are particularly attractive since their analogues have been used as biologically interesting compounds ${ }^{1 a}$ and fluorescent molecules. ${ }^{3}$ For example, compound A exhibited dual antifungal and antibacterial activity with MIC values in the range of $500-1000 \mu \mathrm{g} \mathrm{mL} \mathrm{m}^{-1}$ against fungal strains A. niger, C. albicans and C. tropicalis, while for bacterial strains MIC values were in the range of $32-500 \mu \mathrm{g} \mathrm{mL}{ }^{-1} .{ }^{4}$ Compound $\mathbf{B}$ (NNC 45-0095) possesses comparable estrogen agonist activity with $\mathrm{IC}_{50}=9.5 \mathrm{nM}$ when compared to standard drug moxestrol $\left(\mathrm{IC}_{50}=2.5 \mathrm{nM}\right){ }^{5}$ Polycyclic indolizine $\mathbf{C}$ (Seoul-Fluor) is a novel full-color-tunable fluorescent core skeleton developed by Park and co-workers. ${ }^{6}$ Based on their structural and biological importance, the development of more direct and economical methods for their preparation is highly desirable.

Intramolecular cascade reactions are one of the most ideal processes in organic synthesis from an atom- and step- economical point of view, which can allow for the straightforward and selective construction of complex cyclic molecular structures in a one-pot manner. ${ }^{7}$ In our former study, we developed a silver-mediated sequential oxidative $\mathrm{C}-\mathrm{H}$ functionalization and 5-endo-dig cyclization of 2-alkylpyridines with terminal and internal alkynes. This reaction provides a straightforward route to access biologically important 1,3-disubstituted and 1,2,3-trisubstituted indolizines. ${ }^{8}$ Inspired by this perspective and for the purpose of constructing the fused polycyclic indolizines skeleton, we designed substrate 1, 2-(pyridin-2-yl)acetic acid propargyl esters, and anticipated that in the presence of $\mathrm{Ag}_{2} \mathrm{CO}_{3}$ and $\mathrm{KOAc}$, compound 1 underwent deprotonation and 5-exo-dig cyclization ${ }^{9}$ to produce intermediate 3 , which thus yielded intermediate 4 followed by isomerization. Subsequent intramolecular aromatization of $\mathbf{4}$ would afford fused tricyclic indolizine product $\mathbf{2}$ as shown in Scheme 1. This silver-mediated double cyclization of 2(pyridin-2-yl)acetic acid propargyl esters would provide a rapid, straightforward and atom-economic route to access biologically important fused tricyclic indolizines. Although extensive works have generated a significant number of approaches for the synthesis of indolizines, ${ }^{10}$ the silver-mediated intramolecular cascade annulations of 2-(pyridin-2-yl)acetic acid propargylesters

Scheme 1 Proposed silver-mediated double cyclization of substrate 1.

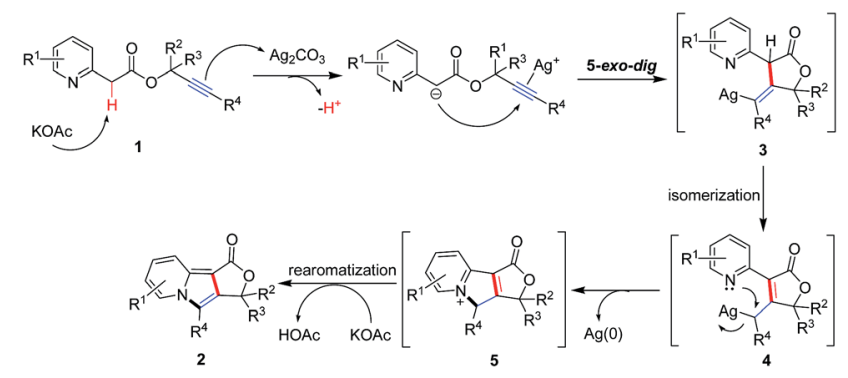

\footnotetext{
${ }^{a}$ State Key Laboratory for the Chemistry and Molecular Engineering of Medicinal Resources, School of Chemistry and Pharmaceutical Sciences of Guangxi Normal University, Guilin 541004, People's Republic of China. E-mail: whengshan@163. com; panym2013@hotmail.com

${ }^{b}$ College of Chemistry and Chemical Engineering, Jishou University, Jishou 416000, People's Republic of China

$\dagger$ Electronic supplementary information (ESI) available: General experimental procedures, and spectral data, NMR spectra, high resolution mass spectra for all compounds, and X-ray crystallographic files (CIF) for 2g. CCDC 1501568. For ESI and crystallographic data in CIF or other electronic format see DOI: 10.1039/c7ra00892a

$\$$ These authors contributed equally to this work.
} 
have not been reported, and it offers an attractive alternative method for the synthesis of fused polycyclic indolizines (Fig. 1).

We began our studies using the easily accessible prop-2-ynyl 2-(pyridin-2-yl)acetate (1a) ${ }^{\mathbf{1 1}}$ as a model substrate for the survey of reaction conditions. As shown in Table 1, the double cyclization of 1a proceeded efficiently in the presence of 2.0 equiv. of $\mathrm{Ag}_{2} \mathrm{CO}_{3}$ and 2.0 equiv. of KOAc in toluene at $100{ }^{\circ} \mathrm{C}$ to afford furo[3,4- $a$ ] indolizin-1(3H)-one (2a) in $90 \%$ yield (Table 1 , entry 1). Without any metal salts, most of the starting material 1a was recovered (Table 1, entry 2), other metal salts, such as $\mathrm{Cu}(\mathrm{OAc})_{2}$, $\mathrm{CdCO}_{3}, \mathrm{Pd}(\mathrm{OAc})_{2}, \mathrm{Pd}\left[\mathrm{P}\left(\mathrm{C}_{6} \mathrm{H}_{5}\right)_{3}\right]_{4}$ or $\mathrm{AgNO}_{3}$, were totally ineffective for this conversion (Table 1, entries 3-7). Whereas AgOTf could also provide the fused tricyclic indolizine product $2 \mathbf{a}$ in $66 \%$ yield (Table 1 , entry 8 ). The screening of bases revealed that the base played an important role in this transformation, and KOAc provided the best yield of $90 \%$ (Table 1 , entry $1 \mathrm{vs}$. entries 10-12). In the absence of base, no reaction occurred (Table 1, entry 9). Solvent screening studies showed that none of the other solvents used, namely, PhCl, DMF, DMSO and $\mathrm{CH}_{3} \mathrm{CN}$ gave a higher yield than toluene (Table 1, entries 13-16). Additionally, $100{ }^{\circ} \mathrm{C}$ was found to be optimal reaction temperature. Although the reaction proceeded much more cleanly when the temperature was lowered to $60^{\circ} \mathrm{C}$, this resulted in a much lower yield of the product (Table 1 , entry 17), and increasing the reaction temperature to $140{ }^{\circ} \mathrm{C}$, the yield of $2 \mathrm{a}$ dramatically decreased to $10 \%$ (Table 1 , entry 18 ). Unfortunately, the mediator and base loading (2.0 equiv.) could not be decreased. Running the reaction at a lower loading of $\mathrm{Ag}_{2} \mathrm{CO}_{3}$ (1.0 equiv.) or KOAc (1.0 equiv.) hampered the reaction efficiency (Table 1 , entries 19 and 20).

A series of substrates 1 were prepared (see the $\mathrm{ESI} \dagger$ for details) to investigate the scope of the double cyclization reaction under the optimized conditions (Table 2). The $\mathrm{R}^{1}$ in the pyridine ring has been substituted with 5-methyl, 6-methyl, 6methoxy, 5-bromo and 5-trifluoromethyl groups whereas $\mathrm{R}^{2}$ and $\mathrm{R}^{3}$ in the propargyl group included alkyl and aryl moieties. The $\mathrm{R}^{4}$ in the alkyne has been substituted by a phenyl group. As shown in Table 2, all the reactions proceeded smoothly to afford the corresponding fused tricyclic indolizines in good to excellent yields (63-90\%). It was found that the electronic properties of the substituent on the pyridine ring had a negligible effect on the yields of the final compounds $(\mathbf{2 b}-\mathbf{2 f})$. While replacing $\mathrm{R}^{2}$ or $\mathrm{R}^{3}$ with an aromatic ring (2m-2r) resulted in somewhat lower yields $(63-78 \%)$ than an aliphatic moiety $(2 \mathbf{g}-2 \mathbf{k}, 86-89 \%)$. Owing to the steric hindrance of the $o$-F and $o$-Cl (Table 2, entry $15)$, the substrate 10 gave the desired product 20 in a lower yield (63\%) compared to the $p$-Cl-substituted $1 \mathrm{~m}(71 \%)$ and $p$-Brsubstituted 1n (75\%). When optically active (S)-but-3-yn-2-yl 2-

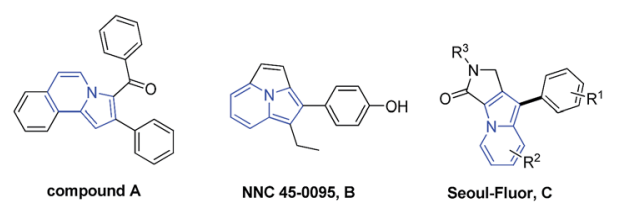

Fig. 1 Examples of fused polycyclic indolizines in pharmaceuticals and fluorescent molecules.
Table 1 Optimization of reaction conditions ${ }^{a}$

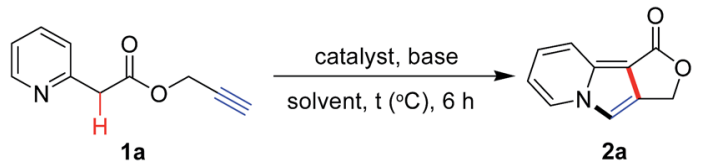

\begin{tabular}{|c|c|c|c|c|c|}
\hline Entry & Catalyst (equiv.) & Base (equiv.) & Solvent & $t\left({ }^{\circ} \mathrm{C}\right)$ & Yield $^{b}(\%)$ \\
\hline 1 & $\mathbf{A g}_{2} \mathbf{C O}_{3}(2)$ & KOAc (2) & Toluene & 100 & 90 \\
\hline 2 & None & KOAc (2) & Toluene & 100 & 0 \\
\hline 3 & $\mathrm{Cu}(\mathrm{OAc})_{2}(2)$ & KOAc (2) & Toluene & 100 & 0 \\
\hline 4 & $\mathrm{CdCO}_{3}(2)$ & KOAc (2) & Toluene & 100 & 0 \\
\hline 5 & $\mathrm{Pd}(\mathrm{OAc})_{2}(2)$ & KOAc (2) & Toluene & 100 & 0 \\
\hline 6 & $\mathrm{Pd}\left[\mathrm{P}\left(\mathrm{C}_{6} \mathrm{H}_{5}\right)_{3}\right]_{4}$ & KOAc (2) & Toluene & 100 & 0 \\
\hline 7 & $\mathrm{AgNO}_{3}(2)$ & KOAc (2) & Toluene & 100 & 0 \\
\hline 8 & AgOAc (2) & KOAc (2) & Toluene & 100 & 66 \\
\hline 9 & $\mathrm{Ag}_{2} \mathrm{CO}_{3}(2)$ & None & Toluene & 100 & 0 \\
\hline 10 & $\mathrm{Ag}_{2} \mathrm{CO}_{3}(2)$ & $\mathrm{NaOH}(2)$ & Toluene & 100 & Trace \\
\hline 11 & $\mathrm{Ag}_{2} \mathrm{CO}_{3}(2)$ & $t$-BuOK (2) & Toluene & 100 & Trace \\
\hline 12 & $\mathrm{Ag}_{2} \mathrm{CO}_{3}(2)$ & $\mathrm{K}_{2} \mathrm{CO}_{3}(2)$ & Toluene & 100 & Trace \\
\hline 13 & $\mathrm{Ag}_{2} \mathrm{CO}_{3}(2)$ & KOAc (2) & $\mathrm{PhCl}$ & 100 & 82 \\
\hline 14 & $\mathrm{Ag}_{2} \mathrm{CO}_{3}(2)$ & KOAc (2) & DMF & 100 & 75 \\
\hline 15 & $\mathrm{Ag}_{2} \mathrm{CO}_{3}(2)$ & KOAc (2) & DMSO & 100 & 28 \\
\hline 16 & $\mathrm{Ag}_{2} \mathrm{CO}_{3}(2)$ & KOAc (2) & $\mathrm{CH}_{3} \mathrm{CN}$ & 100 & 41 \\
\hline 17 & $\mathrm{Ag}_{2} \mathrm{CO}_{3}(2)$ & KOAc (2) & Toluene & 60 & 53 \\
\hline 18 & $\mathrm{Ag}_{2} \mathrm{CO}_{3}(2)$ & KOAc (2) & Toluene & 140 & 10 \\
\hline 19 & $\mathrm{Ag}_{2} \mathrm{CO}_{3}(1)$ & KOAc (2) & Toluene & 100 & 42 \\
\hline 20 & $\mathrm{Ag}_{2} \mathrm{CO}_{3}(2)$ & KOAc (1) & Toluene & 100 & 45 \\
\hline
\end{tabular}

${ }^{a}$ Reactions conditions: $1 \mathrm{a}(0.5 \mathrm{mmol})$, catalyst, base, solvent $(2.0 \mathrm{~mL})$, $100{ }^{\circ} \mathrm{C}$ (except for entry 17 and entry 18) for $6 \mathrm{~h} .{ }^{b}$ Isolated yield of pure product based on 1a. Entry in bold highlights optimized reaction conditions.

(pyridin-2-yl)acetate $\mathbf{1 h}$ was examined as a substrate, to our delight, $(S)$-3-methylfuro[3,4-a]indolizin-1(3H)-one $\mathbf{2 h}$ was formed in $86 \%$ yield (Table 2 , entry 8 ). Additionally, substituting $\mathrm{R}^{4}$ with a phenyl group furnished $2 \mathrm{~s}$ and $2 \mathrm{t}$ in reduced yields of 77 and 66\% respectively (Table 2, entries 19 and 20). The crystallization of compound $2 \mathbf{i}$ from chloroform and ethanol gave a single crystal suitable for X-ray analysis. Fig. 2 illustrates the molecular structure of the fused tricyclic indolizine $\mathbf{2 i}{ }^{12}$

To further support the proposed reaction pathway, additional control experiments were carried out. It was observed that the presence of 2 equiv. of TEMPO (2,2,6,6-tetramethyl-1piperidinyloxy) did not suppress the double cyclization of substrate 1a under optimized conditions, suggesting that a radical mechanism was not likely involved. ESI/MS experiments were performed to gain evidence for the possible intermediates in the proposed mechanism. A mixture of $\mathbf{1 a}(0.5$ $\mathrm{mmol})$, KOAc (1.0 mmol) and $\mathrm{Ag}_{2} \mathrm{CO}_{3}(1.0 \mathrm{mmol})$ in toluene (2.0 $\mathrm{mL}$ ) was reacted at $100{ }^{\circ} \mathrm{C}$ for $30 \mathrm{~min}$ and $50 \mu \mathrm{L}$ of the mixture was used for the ESI analysis in $\mathrm{CH}_{3} \mathrm{CN}$. The ESI/MS analyses showed a peak at $m / z 174.0548$, which was identified as intermediate 5a (see the ESI $\dagger$ ).

In conclusion, we have developed a rapid, simple and efficient double cyclization reaction for the synthesis of fused tricyclic indolizines from easily available starting materials in 
Table 2 Synthesis of fused tricyclic indolizine derivatives ${ }^{a}$

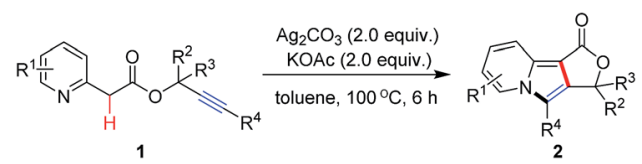

\begin{tabular}{|c|c|c|c|}
\hline Entry & Substrate & Product & Yield $^{b}(\%)$ \\
\hline
\end{tabular}

1

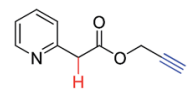

$1 \mathrm{a}$

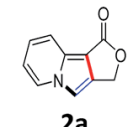<smiles>C#CC(C)(C)OC(=O)Cc1ccc(C)cn1</smiles>

1b<smiles>C#CC(C)(C)OC(=O)Cc1cccc(C)n1</smiles>

$1 c$<smiles>C#CC(C)(C)OC(=O)Cc1cccc(OC)n1</smiles><smiles>C#CC(C)(C)OC(=O)Cc1ccc(Br)cn1</smiles>

$1 e$<smiles>C#CC(C)(C)OC(=O)Cc1ccc(C(F)(F)F)cn1</smiles>

$1 f$<smiles>C#CC(C)OC(=O)Cc1ccccn1</smiles><smiles>C#CC(C)OC(=O)Cc1ccccn1</smiles>

1h<smiles>C#CC(C)(C)OC(=O)Cc1ccccn1</smiles><smiles>C#CC(CCCCC)OC(=O)Cc1ccccn1</smiles>

1j

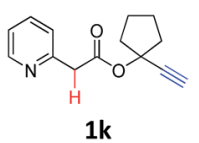<smiles>Cc1ccc2c3c(cn2c1)C(C)(C)OC3=O</smiles>

2b

90

88<smiles>Cc1cccc2c3c(cn12)C(C)(C)OC3=O</smiles>

85

87

2d<smiles>CC1(C)OC(=O)c2c1cn1cc(Br)ccc21</smiles>

89

84<smiles>CC1(C)OC(=O)c2c1cn1cc(C(F)(F)F)ccc21</smiles><smiles>[Z5]Cc1c2c(c3ccccn13)C(=O)OC2C</smiles>

89<smiles>CC1OC(=O)c2c1cn1ccccc21</smiles>

86

87<smiles>CC1(C)OC(=O)c2c1cn1ccccc21</smiles>

88

89
Table 2 (Contd.)

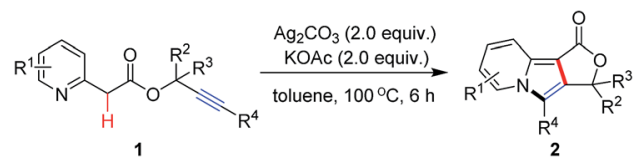

\begin{tabular}{|c|c|c|c|}
\hline Entry & Substrate & Product & Yield $^{b}(\%)$ \\
\hline
\end{tabular}

12

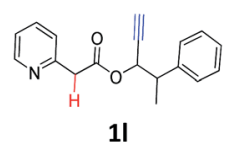<smiles>CC(c1ccccc1)C1OC(=O)c2c1cn1ccccc21</smiles>

86<smiles>C#CC(OC(=O)Cc1ccccn1)c1ccc(Cl)cc1</smiles>

2l

13<smiles>O=C1OC(c2ccc(Cl)cc2)c2cn3ccccc3c21</smiles>

71

$1 \mathrm{~m}$<smiles>C#CC(OC(=O)Cc1ccccn1)c1ccc(Br)cc1</smiles><smiles>O=C1OC(c2ccc(Br)cc2)c2cn3ccccc3c21</smiles>

75

14

1n

$2 n$<smiles>C=C(OC(=O)Cc1ccccn1)c1c(F)cccc1Cl</smiles>

10<smiles></smiles>

63

20<smiles>C=C(OC(=O)c1ccccn1)c1ccc(C)cc1</smiles><smiles></smiles>

78

16<smiles>C#CC(OC(=O)Cc1ccccn1)c1ccccc1C</smiles>

$1 q$

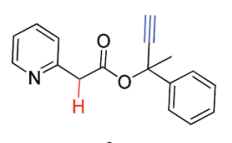

$1 r$<smiles>Cc1ccc(C(C#Cc2ccccc2)OC(=O)Cc2ccccn2)cc1</smiles>

1s<smiles>O=C(OC(C#Cc1ccccc1)c1ccccc1Cl)c1ccccn1</smiles>

$1 t$

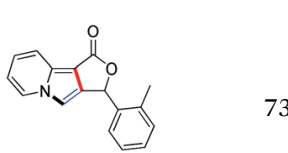

$2 q$<smiles>CC1(c2ccccc2)OC(=O)c2c1cn1ccccc21</smiles>

74

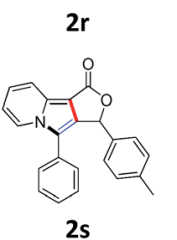

77

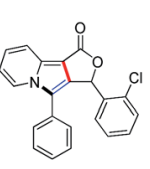

$2 t$

${ }^{a}$ Reaction conditions: $1 \mathrm{a}$ ( $\left.0.5 \mathrm{mmol}\right), \mathrm{Ag}_{2} \mathrm{CO}_{3}$ (2 equiv.), KOAc (2 equiv.), toluene $(2.0 \mathrm{~mL}), 100{ }^{\circ} \mathrm{C}$ for $6 \mathrm{~h} .{ }^{b}$ Isolated yield of pure product based on 1 a. 


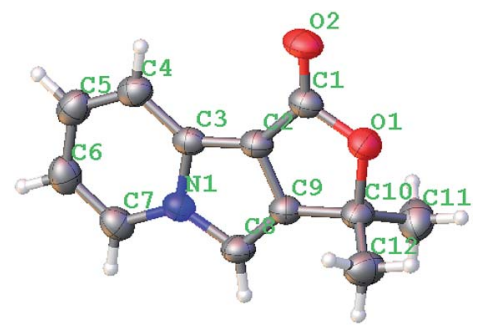

Fig. 2 X-ray crystal structure of fused tricyclic indolizine $2 \mathrm{i}$ (CCDC 1501568).

good to excellent yields. The salient feature of this method involves a silver-mediated 5-exo-dig cyclization and 1,3hydrogen shift followed by an intramolecular cycloisomerization in one pot. Molecular biology studies involving derivatives of this scaffold are currently in progress.

\section{Acknowledgements}

We would like to thank the National Natural Science Foundation of China (21362002 and 81260472), the Ministry of Education of China (IRT_16R15), Guangxi Natural Science Foundation of China (2014GXNSFDA118007, 2016GXNSFGA380005 and 2016GXNSFEA 380001), the State Key Laboratory for the Chemistry and Molecular Engineering of Medicinal Resources (CMEMR2014-A02 and CMEMR2012-A20), Hunan Province Natural Science Foundation of China (2016JJ4075), and Science Research Project of Hunan Provincial Department of Education (16B211).

\section{Notes and references}

1 (a) G. S. Singh and E. E. Mmatli, Eur. J. Org. Chem., 2011, 5237; (b) H. Li, Z. Xia, S. Chen, K. Koya, M. Ono and L. Sun, Org. Process Res. Dev., 2007, 11, 246; (c) J. P. Michael, Nat. Prod. Rep., 2007, 24, 191; (d) J. P. Michael, Nat. Prod. Rep., 2008, 25, 139; (e) S. Hagishita, M. Yamada, K. Shirahase, T. Okada, Y. Murakami, Y. Ito, T. Matsuura, M. Wada, T. Kato, M. Ueno, Y. Chikazawa, K. Yamada, T. Ono, I. Teshirogi and I.-M. Ohtani, J. Med. Chem., 1996, 39, 3636; $(f)$ R. C. Oslund, N. Cermark and M. H. Gelb, J. Med. Chem., 2008, 51, 4708; (g) L.-L. Gundersen, C. Charnock, A. H. Negussie and F. Rise, Eur. J. Pharm. Sci., 2007, 30, 26; (h) O. B. Østby, B. Dalhus, L.-L. Gundersen, F. Rise, A. Bast and G. R. M. M. Haenen, Eur. J. Org. Chem., 2000, 3763; (i) S. Teklu, L. L. Gundersen, T. Larsen, K. E. Malterud and F. Rise, Bioorg. Med. Chem., 2005, 13, 3127; (j) J. Bermudez, C.-S. Fake, G.-F. Joiner, K.-A. Joiner, F.-D. King, W.-D. Miner and G.-J. Sanger, J. Med. Chem., 1990, 33, 1919.

2 (a) K. M. Elattar, I. Youssef and A. A. Fadda, Synth. Commun., 2016, 46, 719; (b) J.-B. Xia and S.-L. You, Org. Lett., 2009, 11, 1187; (c) H. Hu, Y. Liu, H. Zhong, Y. Zhu, C. Wang and M. Ji, Chem.-Asian J., 2012, 7, 884; (d) Q. Wu, D. Zhao, X. Qin, J. Lan and J. You, Chem. Commun., 2011, 47, 9188.
3 (a) Y.-M. Shen, G. Grampp, N. Leesakul, H.-W. Hu and J.-H. Xu, Eur. J. Org. Chem., 2007, 3718; (b) B. Liu, Z. Wang, N. Wu, M. Li, J. You and J. Lan, Chem.-Eur. J., 2012, 18, 1599; (c) A. Vlahovici, M. Andrei and I. Druta, J. Lumin., 2002, 96, 279; (d) A. Vlahovici, I. Druta, M. Andrei, M. Cotlet and R. Dinica, J. Lumin., 1999, 82, 155; (e) T. Mitsumori, M. Bendikov, O. Dautel, F. Wudl, T. Shioya, H. Sato and Y. Sato, J. Am. Chem. Soc., 2004, 126, 16793.

4 A. Hazra, S. Mondal, A. Maity, S. Naskar, P. Saha, R. Paira, K. B. Sahu, P. Paira, S. Ghosh, C. Sinha, A. Samanta, S. Banerjee and N. B. Mondal, Eur. J. Med. Chem., 2011, 46, 2132.

5 A. S. Jorgensen, P. Jacobsen, L. B. Christiansen, P. S. Bury, A. Kanstrup, S. M. Thorpe, S. Bain, L. Naerum and K. Wassermann, Bioorg. Med. Chem. Lett., 2000, 10, 399.

6 (a) E. Kim, M. Koh, J. Ryu and S. B. Park, J. Am. Chem. Soc., 2008, 130, 12206; (b) E. Kim, M. Koh, B. J. Lim and S. B. Park, J. Am. Chem. Soc., 2011, 133, 6642; (c) E. Kim, Y. Lee, S. Lee and S. B. Park, Acc. Chem. Res., 2015, 48, 538.

7 For some reviews, see: (a) M. Malacria, Chem. Rev., 1996, 96, 289; (b) K. A. Millera and R. M. Williams, Chem. Soc. Rev., 2009, 38, 3160; (c) L.-Q. Lu, J.-R. Chen and W.-J. Xiao, Acc. Chem. Res., 2012, 45, 1278; (d) K. C. Majumdar, RSC Adv., 2011, 1, 1152.

8 X. Tan, Y. Liang, F. Bao, H. Wang and Y. Pan, Tetrahedron, 2014, 70, 6717.

9 (a) L. Wang, S.-Y. Cai, X.-Y. Xing, Y. Gao, T. Wang and D. Z.-G. Wang, Org. Lett., 2013, 15, 2362; (b) K.-H. Kwon, C. M. Serrano, M. K. L. R. Barrows and R. E. Looper, Org. Lett., 2014, 16, 6048; (c) C. Gronnier, P. F. D. Bel, G. Henrion, S. Kramer and F. Gagosz, Org. Lett., 2014, 16, 2092; (d) D. Hack, P. Chauhan, K. Deckers, G. N. Hermann, L. Mertens, G. Raabe and D. Enders, Org. Lett., 2014, 16, 5188; (e) T. Godet, C. Vaxelaire, C. Michel, A. Milet and P. Belmont, Chem.-Eur. J., 2007, 13, 5632; (f) E. Parker, N. Leconte, T. Godet and P. Belmont, Chem. Commun., 2011, 47, 343.

10 For representative examples, see: (a) Y. Shi and V. Gevorgyan, Chem. Commun., 2015, 51, 17166; (b) S. Tang, K. Liu, Y. Long, X. Qi, Y. Lan and A. Lei, Chem. Commun., 2015, 51, 8769; (c) X. Wang, S. Li, Y. Pan, H. Wang, H. Liang, Z. Chen and X. Qin, Org. Lett., 2014, 16, 580; (d) A. N. Pandya, J. T. Fletcher, E. M. Villa and D. K. Agrawal, Tetrahedron Lett., 2014, 55, 6922; (e) H. Hu, J. Feng, Y. Zhu, N. Gu and Y. Kan, RSC Adv., 2012, 2, 8637; (f) Y. Liu, H.-Y. Hu, Q.-J. Liu, H.-W. Hu and J.-H. Xu, Tetrahedron, 2007, 63, 2024; (g) R. Azpíroz, A. D. Giuseppe, R. Castarlenas, J. J. Pérez-Torrente and L. A. Oro, Chem.Eur. J., 2013, 19, 3812.

11 B. Sahoo, M. N. Hopkinson and F. Glorius, Angew. Chem., Int. Ed., 2015, 54, 15545.

12 CCDC 1501568 (2i) contains the supplementary crystallographic data for this paper. 